\title{
Land sharing between cultivated and wild plants: urban gardens as hotspots for plant diversity in cities
}

\author{
Birgit Seitz ${ }^{1}$. Sascha Buchholz ${ }^{1,2} \cdot$ Ingo Kowarik $^{1,2} \cdot$ Johann Herrmann $^{1} \cdot$ Leonie Neuerburg $^{1} \cdot$ Julian Wendler $^{1}$. \\ Leonie Winker ${ }^{1} \cdot$ Monika Egerer $^{1,3}$ (1)
}

Accepted: 21 December 2021 / Published online: 24 January 2022

(c) The Author(s) 2022

\begin{abstract}
Plant communities in urban gardens consist of cultivated species, including ornamentals and food crops, and wild growing species. Yet it remains unclear what significance urban gardens have for the plant diversity in cities and how the diversity of cultivated and wild plants depends on the level of urbanization. We sampled plants growing within 18 community gardens in Berlin, Germany to investigate the species diversity of cultivated and wild plants. We tested species diversity in relation to local and landscape-scale imperviousness as a measure of urbanity, and we investigated the relationship between cultivated and wild plant species within the gardens. We found that numbers of wild and cultivated plant species in gardens are high - especially of wild plant species - independent of landscape-scale imperviousness. This suggests that all community gardens, regardless of their urban contexts, can be important habitats for plant diversity along with their role in urban food provision. However, the number of all species was negatively predicted by local garden scale imperviousness, suggesting an opportunity to reduce imperviousness and create more habitats for plants at the garden scale. Finally, we found a positive relationship between the number of cultivated and wild growing species, which emphasizes that community gardens present a unique urban ecosystem where land sharing between cultivated and wild flora can transpire. As the urban agriculture movement is flourishing worldwide with gardens continuously and spontaneously arising and dissipating due to urban densification, such botanical investigations can support the argument that gardens are places for the reconciliation of plant conservation and food production.
\end{abstract}

Keywords Berlin · Conservation · Novel ecosystems · Urban agriculture · Urbanization · Reconciliation ecology

\section{Introduction}

Rapid urbanization has led to the loss of green spaces in cities, with a majority of the world's population currently living and projected to live in cities by 2050 (UN-Habitat 2016). Consequently, urban gardens have become increasingly important for food production, recreation or social interaction (Čepić and Tomićević-Dubljević 2017; Lin and

Monika Egerer

monika.egerer@tum.de

1 Department of Ecology, Technische Universität Berlin, Rothenburgstr. 12, Berlin 12165, Germany

2 Berlin-Brandenburg Institute of Advanced Biodiversity Research (BBIB), Berlin 14195, Germany

3 Department of Life Science Systems, TUM School of Life Sciences, Technical University of Munich, Hans Carl-von-Carlowitz-Platz 2, Freising 85354, Germany
Egerer 2020). Gardens thereby support a wide array of ecosystem functions, including food provision, habitat for biodiversity, carbon sequestration, climate mitigation and water retention (Lin et al. 2015), and are the focus of recent urban ecology research (Gaston et al. 2005; Guitart et al. 2012; Vergnes et al. 2013; Philpott and Bichier 2017; Clucas et al. 2018; Frey and Moretti 2019).

As part of urban green infrastructure, gardens contribute significantly to urban plant diversity (Davies et al. 2009; Goddard et al. 2010; Cameron et al. 2012). The composition of plant populations in cities is influenced by multiple urban drivers including human management, climate, pollution, land use change and biological invasions (Pyšek et al. 2010; Kowarik 2011; Lososová et al. 2012; Aronson et al. 2016; Piana et al. 2019; Swan et al. 2021). In contrast to rural regions, cities are characterized by high habitat heterogeneity including novel urban habitats with great potential for biodiversity (Kowarik 2011; Swan et al. 2021), 
encompassing parks (Fischer et al. 2016; Vojík et al. 2020), cemeteries (Kowarik et al. 2016; Löki et al. 2019), urban woodlands (Trentanovi et al. 2013; Kowarik et al. 2019), wastelands (Bonthoux et al. 2014), railways (Westermann et al. 2011) and gardens (Thompson et al. 2003; Loram et al. 2008; Pergl et al. 2016; Frey and Moretti 2019). As a consequence, plant species richness in urban ecosystems can be higher than in non-urban ecosystems (Kühn et al. 2004; Knapp et al. 2009; Pyšek et al. 2010; Faeth et al. 2011; Kowarik 2011).

A high proportion of nonnative species and anthropogenic processes that drive plant dispersal, foster plant diversity in cities (Swan et al. 2021). Trade, traffic and horticulture seem to be the most prominent dispersal pathways (von der Lippe and Kowarik 2009; Kleunen et al. 2018). Ornamental plants play the largest role among introduced species, followed by plants for agricultural or forestry purposes (Kowarik 2005). For this reason, novel urban ecosystems such as community gardens designed for food production and ornamental purposes provide an interesting system to examine plant species diversity. In these agroecosystems, plant species assemble through gardeners' preferences (e.g., ornamental) and motivations to garden (e.g., food, nature connection) (Clarke and Jenerette 2015; Egerer et al. 2019b; Philpott et al. 2020), but also through both spontaneous and anthropogenic seed dispersal (von der Lippe and Kowarik 2009; Piana et al. 2019). Moreover, the flora of gardens is particularly influenced by the interaction of people's activities like planting, weeding (including using herbicides), watering, soil cultivation and fertilizing (Kendal et al. 2012; Padullés Cubino et al. 2018, 2020).

There is only a small number of comprehensive studies about the plant diversity in urban gardens (e.g. Thompson et al. 2003; Loram et al. 2008), and only a few analyze both cultivated and wild growing plants (e.g. Jaganmohan et al. 2012; Frey and Moretti 2019). Such assessments are needed to offer a fundamental ecological understanding of the taxonomic and functional diversity harbored in these systems that underlies ecosystem processes. Furthermore, such assessments can have important urban policy and planning outcomes for the management of urban greenspaces to enhance urban biodiversity (e.g., including community gardens as open spaces into public parks and places, conservation and integration of spontaneous vegetation in urban greenspaces) (Goddard et al. 2010; Lin and Egerer 2020). Finally, high plant diversity in urban gardens can have profound positive impacts on associated biodiversity, including arthropods (Shrewsbury et al. 2004; Faeth et al. 2005; Bang et al. 2012; Kaluza et al. 2018; Egerer et al. 2019a; Buchholz et al. 2020), birds (Daniels and Kirkpatrick 2006; Threlfall et al. 2017) and mammals (Van Helden et al. 2020).

Here, we assessed both the cultivated and spontaneous plant species diversity growing within 18 urban community gardens across the metropolitan region of Berlin, Germany. In Berlin, community gardens are growing in popularity because they are not only source for food but also provide a wide range of ecosystem services including social interaction and environmental education (Guitart et al. 2012; Barthel and Isendahl 2013; Gregory et al. 2016). Community gardens are characterized by the cultivation of vegetable patches or raised beds on vacant lots, parking areas or rooftops by local residents. As horticultural spaces for the cultivation of crops and ornamental plants they also support space for spontaneously growing plants. Berlin historically had abundant greenspaces in most neighborhoods (Kowarik 2019), but the city is also rapidly densifying and green spaces are being lost (Kabisch and Haase 2014). In the Berlin context, community gardens are an increasingly valuable greenspace from a social-ecological perspective, but ecological research within these urban agroecosystems is lacking. We have little information about the plant species growing in these systems, which could inform how these systems differ from or share parallels with other greenspaces. To fill this gap, we systematically documented the cultivated and wild plant species (excluding grasses) within selected gardens to ask: (1) What is the species richness of all, cultivated (food crops, ornamentals) and wild growing (wild, weeds, spontaneous) plants in urban gardens? (2) How does plant species richness vary with local and landscape-scale urbanization (imperviousness)? (3) What is the relationship between cultivated and wild plant species richness?

\section{Methods}

\section{Study sites}

Our study system included 18 urban community gardens distributed across Berlin, Germany (Fig. 1). The gardens vary in age, size, number of participants and governance structure (Supplementary Information (SI) Appendix 1). Furthermore, the gardens vary in landscape surroundings and local management (Fig. 2). In some gardens the beds are individually managed (i.e., plant selection, irrigation, soil amending) by households in an allotment style, while in other gardens the beds are collectively managed by all participants. The gardens were a part of a larger study conducting research on wild pollinators. This research focuses on the largely herbaceous plant community in the gardens.

\section{Data collection}

\section{Plant data}

We visited the gardens three times from May to August 2020. Of the 18 gardens, four were only assessed twice due 
Fig. 1 Distribution of 18 community gardens (yellow boxes) investigated in this study across an urbanization gradient in the city of Berlin, Germany. Gardens with endangered wild growing species (Seitz et al. 2018) are indicated with a red box

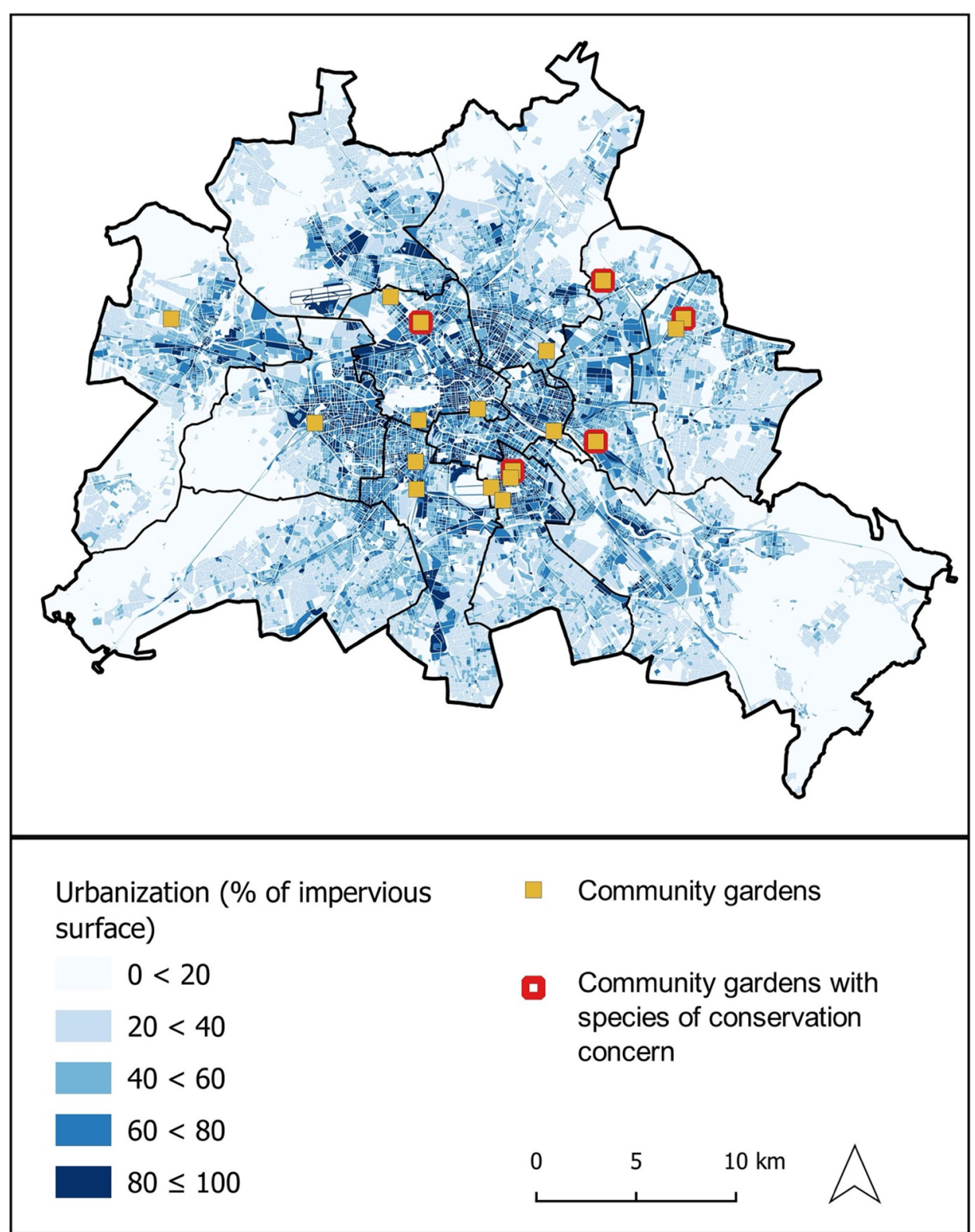

to logistical constraints. We established a $400 \mathrm{~m}^{2}$ sampling plot, with a side length of $20 \times 20$-m in the center of each garden within which to concentrate our measurements. We altered the size of the sampling plot where necessary (i.e., where gardens were more narrow than they were wide, we created a $40 \times 10-\mathrm{m}$ plot). In this sampling plot, we randomly placed eight $1 \times 1-\mathrm{m}$ quadrats within which we identified all herbaceous plants (except grasses) to species level. The selection of the quadrats was performed using randomly determined distance values, measured along transects from the baseline of the sampling plot. We also documented small woody species within the plots including juvenile fruit trees and berry shrubs as part of the herb layer as many play a role in food production (e.g., Ribes and Rubus). Woody species in the shrub or tree layer exceeding one meter in height were not considered. These $1 \times 1-\mathrm{m}$ plots were selected anew on each study day without overlap, which means a total of 16 or 24 plots were studied in each garden. We excluded the species identification of grasses because the study took place in the context of a pollinator study and grass species flowers are not relevant for pollinators. For plant identification and nomenclature, we used Jäger et al. $(2016,2017)$ and the PlantNet Handheld Application (see: https://plantnet. org/en/).

We identified the species status characterization, namely whether the plant species was: (i) cultivated (crop, ornamental) or (ii) wild (wild, weed, spontaneous vegetation). If species occurred as wild and cultivated, we 

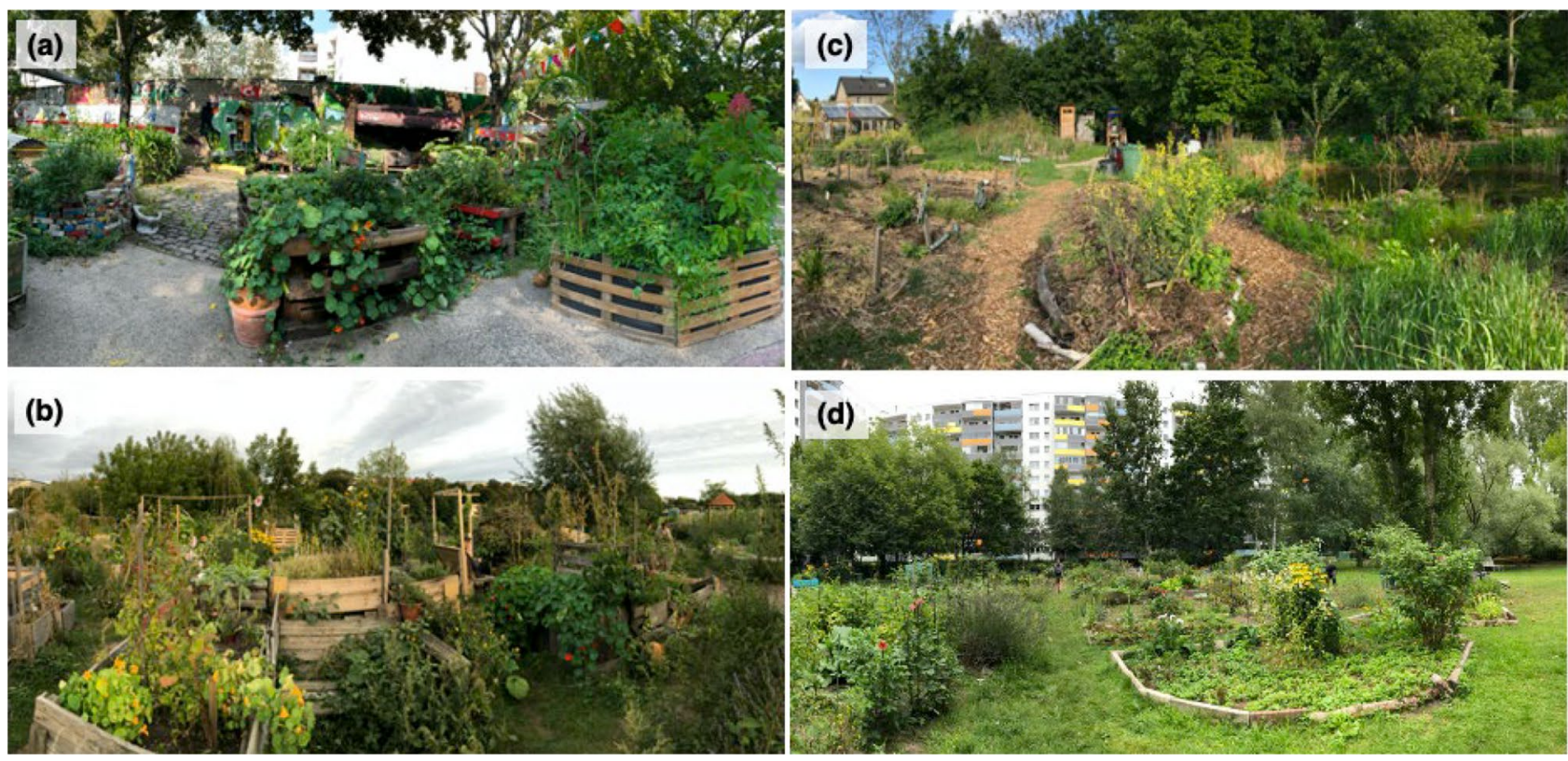

Fig. 2 Examples of four community gardens assessed in the study: one with high local imperviousness and low plant diversity (a; Wedding); one with low local imperviousness and high plant diversity (b; Tempelhof); one with high landscape imperviousness, low local

documented them in both status groups. In addition, we classified plants into native and nonnative species and split the latter into archaeophytic and neophytic species in Berlin. The differentiation of these status categories followed the mapping criteria of the floristic mapping of Berlin (Seitz et al. 2012). Cultivated species were intentionally sown or planted native or nonnative species. The classification as "cultivated" followed taxonomic criteria (taxa only known as cultivated species or varieties like some crops), morphological traits (e.g., for Daucus carota) or traces of cultivation (cultivation in rows or beds, promotion by weeding, component of typical "wildflower" seed mixtures). Wild growing species were species with exclusively spontaneous occurrences, that were not directly settled by humans (including spontaneous occurrences of cultivated species or escapes from cultivation which were not intentionally planted or sown). In addition, we documented all wild growing grasses in the plots as an own category, but without identification to species, except cultivated grass species such as Zea mays, due to their importance as crops. We summarized the total richness of plant species identified across all plots within each garden for each sampling round and across all sampling rounds. Where species were only identified to genus, we only counted those samples in the total plant species richness if there was not an observation of the same genus at the species level (i.e., we did not count Brassica spec. if, for example, Brassica oleracea was observed within that garden). imperviousness and high plant diversity (c; Prenzlauer Berg); and one with low landscape imperviousness, low local imperviousness and low plant diversity (d; Hohenschönhausen). Photos: Monika Egerer

\section{Local and landscape imperviousness data}

To collect information on the level of urbanization within each site and within the surrounding landscape, we used imperviousness (i.e., sealed surface) as a representative measure of urbanization (von der Lippe et al. 2020). At the local habitat scale, within each $1 \times 1$-m garden plot, we assessed the percent imperviousness including concrete and rock. To measure landscape-scale imperviousness, we collected publicly available data on the surrounding landscape features of each garden from the Berlin Environmental Atlas (Senatsverwaltung für Stadtentwicklung und Umwelt 2016). Here we measured the proportion of imperviousness at a $2 \times 2-\mathrm{m}$ resolution within $500-\mathrm{m}, 1-\mathrm{km}$ and $2-\mathrm{km}$ buffers using the Zonal statistics tool in QGIS software v. 2.18.0 (QGIS Development Team 2018).

\section{Data analysis}

To test whether local or landscape scale urbanization (imperviousness) predicts the characteristics of the plant community within gardens, we built models with the following response variables: (i) total plant species richness; (ii) cultivated plant species richness; (iii) wild plant species richness; and (iv) the ratio of wild to cultivated plant species. The species richness of all plant species documented in the garden for each sampling round was the response variable, and the percent of local imperviousness and the percent of 
landscape imperviousness and their interaction were the predictor variables. Imperviousness was scaled using the scale function in R. Preliminary analyses revealed that $2-\mathrm{km}$ provided the best model fit for landscape imperviousness based on Akaike's Information Criterion (AIC), where 2-km had a lower AIC value ( $<2$ AIC points) than the other models (Burnham and Anderson 2002). Thus, we used 2-km spatial scale predictor variable in all models. Garden site was included as a random effect. Generalized linear mixed effects models fit by maximum likelihood were fit with a Poisson family distribution for species richness analyses, and linear mixed effects models were fit with a gaussian distribution for ratio models. For all models, we evaluated model fit using AIC and an analysis of variance.

To test whether there is a relationship between the species richness of cultivated and wild plants, we used Pearson correlation tests using the cor.test function in $\mathrm{R}$ with each site observation per sampling round as a replicate. In gardens where a given species was classified as both a cultivated and a wild plant due to the context in which the plant was observed, we considered the most common class in which it was observed or its common state in the literature.

All statistical analyses were performed in R v. 3. 6.0 ( R Development Core Team 2016).

\section{Results}

Of 3,604 plant observations across all 18 gardens, we documented 404 taxa representing 255 genera (SI Appendix 2 ). Some plants were only identified to genus level (65 taxa). We recorded 194 cultivated taxa, 184 wild growing taxa (spontaneous taxa), and 26 taxa as wild and cultivated. The number of plant species per sampling round ranged between gardens, from 18 to 81 species observed within a garden (Table 1; SI Appendix 2). The average number of species documented in a sampling round across all gardens was $44.12 \pm 14.14$, while the average total

Table 1 Summary statistics of main variables collected in the gardens for this study, for each monthly observation within a garden ( $\mathrm{Min}=$ minimum value $; \mathrm{Max}=$ maximum $; \mathrm{SD}=$ standard deviation)

\begin{tabular}{|c|c|c|c|c|}
\hline & Min & Max & Mean & SD \\
\hline Total plant species richness & 18.00 & 81.00 & 44.12 & 14.14 \\
\hline Cultivated plant species richness & 3.00 & 38.00 & 16.50 & 7.86 \\
\hline Wild plant species richness & 10.00 & 51.00 & 27.62 & 9.78 \\
\hline Ratio of cultivated:wild plants & 0.15 & 2.00 & 0.65 & 0.38 \\
\hline \% Impervious@ 1 m$^{2}$ & 0.00 & 72.00 & 17.10 & 25.16 \\
\hline \% Impervious@ 500 m² $^{2}$ & 31.12 & 85.94 & 60.18 & 14.44 \\
\hline \% Impervious@ 1000 m$^{2}$ & 33.46 & 73.44 & 57.10 & 12.65 \\
\hline \% Impervious@ 2000 m² $^{2}$ & 34.60 & 73.12 & 56.12 & 9.83 \\
\hline
\end{tabular}

number of species per garden was $83.44 \pm 21.78$ (Table 1 ). Gardens with highest total species numbers across all sampling periods were Spiel/Feld Marzahn (117; Marzahn, Berlin), Allmende-Kontor (115; Tempelhof, Berlin) and Kiezgarten Fischerstraße (111; Rummelsburg, Berlin), while the garden with lowest species number was Inselgarten (41; Schöneberg, Berlin) (SI Appendix 1).

Cultivated plants represented $27.12 \%$ of all plant species observations. Wild plants represented a majority, with $64.62 \%$ of all observations. The most common species among crops were Solanum lycopersicum (tomato; $3.5 \%$ of all observations), Beta vulgaris (e.g., chard, beet), Cucurbita pepo (e.g., squash, zucchini, pumpkin) and Fragaria $x$ ananassa (strawberry). Some species were only observed once across all observations (31.44\% of all species observations). The most frequent (i.e., number of occurrences observed across all $1 \times 1-\mathrm{m}$ plot) ornamental plant was Calendula officinalis, other ornamentals with high frequency were Centaurea cyanus, Tagetes spec., and Helianthus annuus. Some species were documented with both cultivated and wild growing (spontaneous) populations, for example, Daucus carota occurred as a cultivar (carrot) and as a wild form. 151 species were native (including archaeophytes), 208 species neophytes and 45 species determined only on genus level were not assigned to a status (Seitz et al. 2012, SI Appendix 2).

The most common species among wild plants were Chenopodium album, Diplotaxis tenuifolia, Polygonum aviculare, Stellaria media, Taraxacum officinale, and Urtica dioica. Among all species, we documented 19 species of conservation concern: four species of the Red List Germany (Metzing et al. 2018) and 17 species of the Red List Berlin (Seitz et al. 2018) (SI Appendix 2). We found 13 species of conservation concern were cultivated species, and six were wild growing species. Among the wild growing plants, we found two species threatened with extinction in Berlin (category 1): Anthemis arvensis and Verbena officinalis, both species of sandy and loamy fields. Galium spurium, a species classified as extinct in Berlin (category 0) was recorded in a raised bed in a rooftop community garden.

\section{Total plant species richness in relation to urbanization at the landscape and local scale}

Total plant species richness was negatively predicted by local scale imperviousness $(\mathrm{F}=6.38 ; \mathrm{P}=0.01$; Fig. 3 ; SI Appendix 3). However, plant species richness within gardens was not predicted by the landscape scale imperviousness surrounding gardens within $2 \mathrm{~km}(\mathrm{~F}=1.52 ; \mathrm{P}=0.27)$, nor the interaction between local and landscape imperviousness $(\mathrm{F}=0.49 ; \mathrm{P}=0.27)(\mathrm{SI}$ Appendix 3$)$. 
Fig. 3 Relationships between species richness of all $(\mathbf{a}-\mathbf{b})$, cultivated (c-d), and wild plants (e-f) and urbanization at landscape- and local garden scale. Lines in $\mathbf{b}, \mathbf{d}$, and $\mathbf{f}$ represent relationships determined from generalized linear models fit with Poisson distribution. No regression line represents no relationship found in the statistical analysis (SI, Appendix 3)

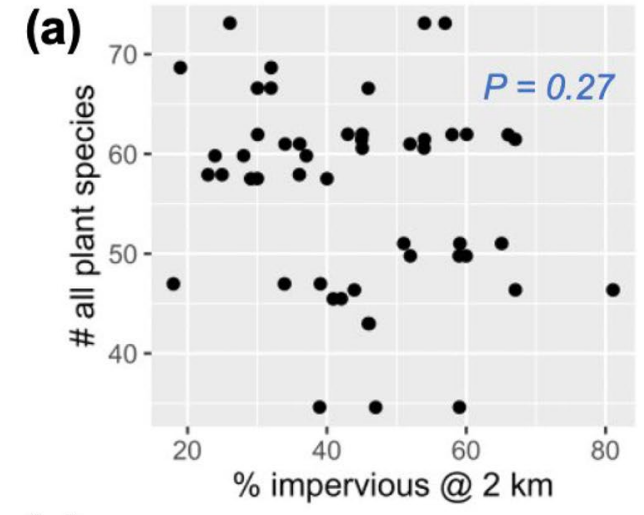

(c)
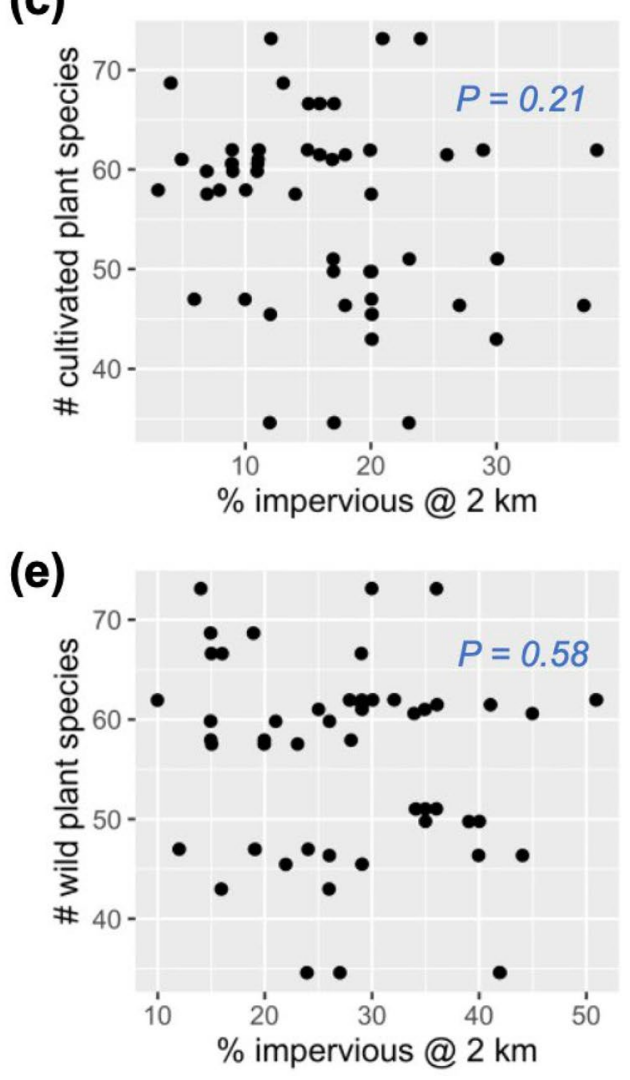

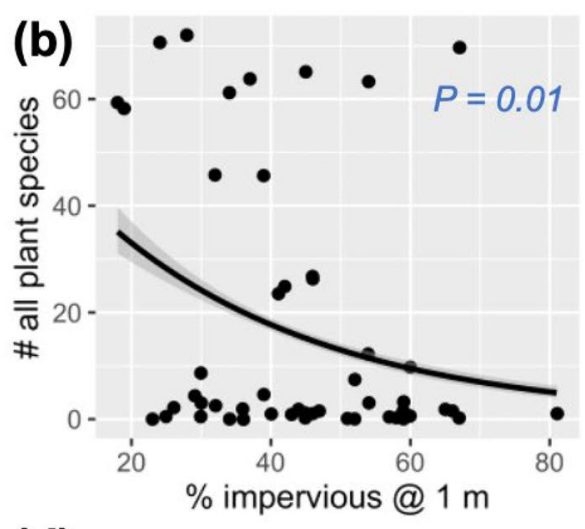

(d)
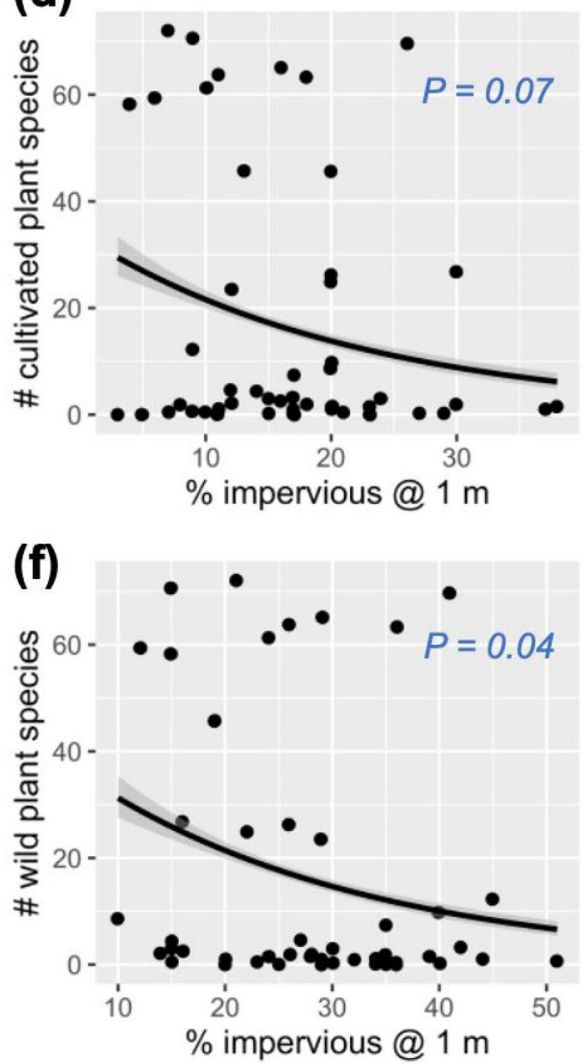

\section{Cultivated and wild plant species richness in relation to urbanization at the landscape and local scale}

Landscape imperviousness did not predict cultivated or wild plant species richness (SI Appendix 3). Although local scale imperviousness did not predict cultivated plant species richness $(\mathrm{F}=3.57 ; \mathrm{P}=0.07)$, local imperviousness did negatively predict wild plant species richness $(F=3.35$; $\mathrm{P}=0.04$ ) (Fig. 3). No variables predicted the relationship (ratio) of cultivated to wild plant species richness (SI Appendix 3).

\section{Relationship between cultivated and wild plants}

The ratio of wild to cultivated plant species richness varied across gardens (Fig. 4a). The abundance and species richness of cultivated and wild plants observed within gardens were positively correlated: the richness of cultivated plants 
Fig. 4 The ratio of wild to cultivated plants varied across gardens $(\mathbf{a})$; here a " 1 " represents an equal representation of wild to cultivated species within a garden. Less than 1 indicates more wild plants, while greater than 1 represents more cultivated species. The abundance and species richness of cultivated and wild plants observed within gardens were positively correlated: the cultivated richness of plants positively correlated with the richness of wild plants $(\mathrm{r} \approx 0.29 ; \mathrm{p}=0.038 ; \mathbf{b})$ (a)

(b)

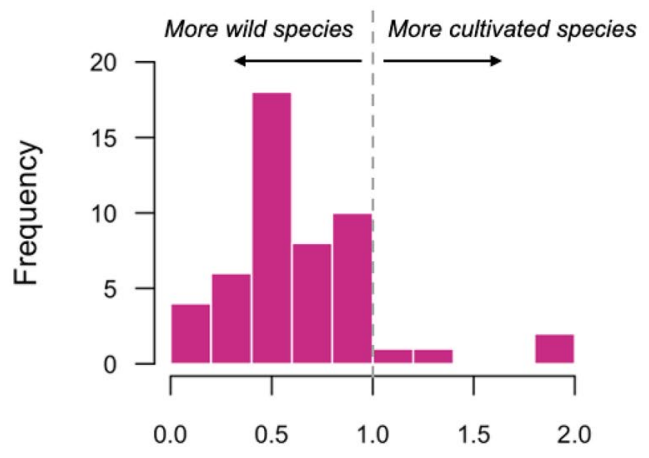

Ratio of cultivated:wild plants

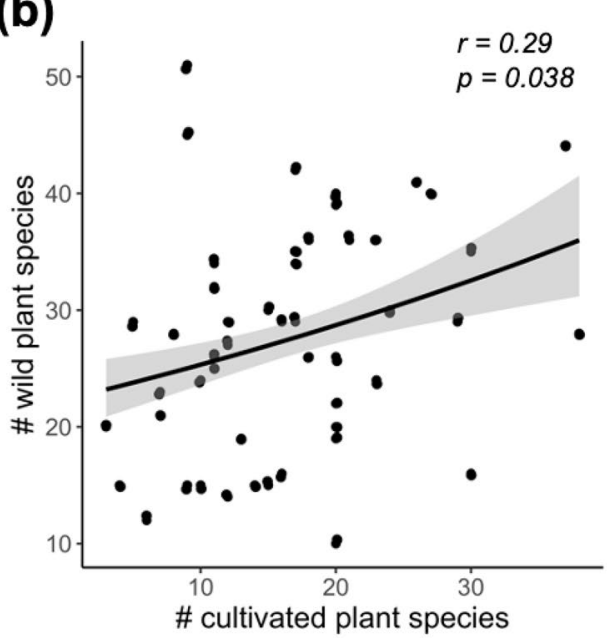

positively related to the richness of wild plants $(r=0.29$; $\mathrm{p}=0.038)($ SI Appendix 4; Fig. 4b).

\section{Discussion}

Our work in one of Berlin's novel urban ecosystem types - urban community gardens - demonstrates the high biodiversity of both cultivated and wild growing plants within this system, and illustrates an example for high plant diversity in cities (Kühn et al. 2004; Knapp et al. 2009; Kowarik 2011). We found that these gardens are rich in plant species, supporting a wide range of food and ornamental crops, but that wild growing plants represent the majority of all plant species. Indeed, six wild growing plant species we documented are actually endangered or extinct in Berlin (Seitz et al. 2018). This underlies the importance of community gardens for nature conservation within a production-focused system (Goddard et al. 2010; Borysiak et al. 2017; Cabral et al. 2017). We elaborate on three main findings of our work: (1) community gardens harbor both high cultivated plant diversity that supports urban food production and high wild plant diversity, potentially representing a high fraction of diversity within the urban landscape; (2) this plant diversity is independent of landscape-scale imperviousness, though local-scale imperviousness may reduce the potential for novel ecosystems to support wild plant diversity; and (3) cultivated and wild plant species coexist with potential for reconciling conservation-production trade-offs sensu "land sharing".

\section{High diversity of cultivated and wild growing plant species within urban gardens}

In 18 community gardens we found 404 different taxa (excluding grasses), including 194 cultivated and 184 wild growing species. The number of wild growing species corresponds to $7 \%$ of the total number of species found in Berlin (Seitz et al. 2012). Kronenberg and Kowarik (1989) recorded 400 (257 cultivated and 143 wild growing) species in five domestic gardens in Berlin. Biodiversity assessments in allotment gardens and community gardens in Leipzig, Germany, showed lower species numbers, with 290 (150 cultivated and 140 wild growing) species in six allotment gardens and 255 (98 cultivated and 157 wild growing) species in six community gardens (Cabral et al. 2017). Investigations of the spontaneous flora in allotment gardens in Poznan, Poland showed higher species numbers with 358 species in eleven gardens (Borysiak et al. 2017). Studies on plant diversity of domestic gardens in the UK showed also higher numbers of both cultivated and spontaneous growing plant species (1166 species in 61 gardens in Sheffield (Smith et al. 2006), 1051 species in 267 gardens in 5 different cities (Loram et al. 2008)). In contrary to these studies that investigated more gardens and/or recorded the whole flora using an inventory approach, we investigated only random samples and excluded grasses. Species numbers may be higher in domestic gardens than in community gardens, as they tend to have longer continuity of use while community garden participants or garden management may change each year. In addition, the management of community gardens focuses predominantly on the cultivation of crops, that are in some gardens provided by the garden administration for all participants.

Compared to other urban habitats in Berlin, total species richness of wild growing species in community gardens is lower than was found in inventory studies in tenant gardens in residential areas (Zerbe et al. 2003), but is comparable to urban woodland (165 species in Robinia stands, 213 species in Betula stands (Trentanovi et al. 2013)). The average total number of species per garden was approximately 84 species; comparing this with a study of the floristic composition 
of different urban habitats in 32 European cities (Lososová et al. 2012), the species numbers in gardens were slightly lower than the average of all habitats, but equal to parks and boulevards. However, the comparison of species numbers with these studies of other urban habitats in Berlin and Europe is limited because study plots in European habitats were much larger (1 ha) than in our study.

The high proportion of wild growing plants underlines the potential of community gardens as habitat for wild growing species in cities. This is also in line with the investigations of plants in allotment and community gardens in Leipzig and Poznan (Borysiak et al. 2017; Cabral et al. 2017). Other studies about domestic gardens have shown that the alpha diversity of plant species within gardens can produce high gamma diversity across a city landscape (Loram et al. 2008). Our work in Berlin emphasizes this ecological pattern, and further underscores the food provision and botanical conservation potential of community gardens.

From a horticultural perspective, we found that gardens have many different cultivated food and flower crops involved in urban food production. The common crops grown in these gardens (e.g., Solanum lycopersicum, Fragaria $\times$ ananassa, Cucurbita pepo, Beta vulgaris) supports other studies in community gardens elsewhere (Philpott et al. 2020). Yet some interesting "novel" crops were also found, including Glycine max (soy bean) in one garden, and Perilla frutescens (shiso) in another garden. This could reflect gardener multicultural diversity (Lin and Egerer 2020; Philpott et al. 2020) or that gardeners are experimenting with "untraditional" crop plants in the German context. Also, historically important and "forgotten" crops (Krausch 1992) like Amaranthus caudatus, Nicotiana tabacum (tobacco) and Ornithopus sativus (serradella) or medicinal herbs like Artemisia abrotanum, Silybum marianum or Leonurus cardiaca were cultivated. Community gardens can thus contribute to the preservation of the genetic diversity of rare crops (Galluzzi et al. 2010; Barthel and Isendahl 2013; Taylor and Mione 2019). Though we did not estimate the harvest amount of fruit and vegetable production within these gardens, even small-scale, but highly intensive species-rich systems like gardens can contribute to healthy diets and reduce financial barriers to organic fruits and vegetables (Alaimo et al. 2008).

From a botanical conservation perspective, these gardens harbor a diverse assemblage of flora, several of which are of conservation concern in the region and represent a multifaceted natural history of garden flora. Among the wild growing species, we found six endangered species (Seitz et al. 2018). Three species (Anthemis arvensis, Galium spurium, Lathyrus tuberosus) are typical for agroecosystems and grow on sandy and loamy fields (Schneider et al. 1994; Jäger et al. 2017), and three species (Barbarea vulgaris, Leonurus cardiaca, Verbena officinalis) are species of ruderal areas and roadsides in villages (Jäger et al. 2017), Leonurus and Verbena were historically used as medicinal plants (Krausch 2007). They have become rare in the intensive cultivated landscape and now find suitable habitats in extensively managed gardens. Although these species occurred only in one or two gardens and their populations were small, it demonstrates the potential of urban gardens as a space for rare and endangered species of agricultural and rural areas. While population survival of endangered plant species is challenging in many urban habitats, greenspaces in Berlin have been shown to harbor established populations of some endangered species of ruderal areas (Planchuelo et al. 2020). In community gardens, these plants could also benefit from organic cultivation and avoidance of herbicides, which was also documented in studies of organic and conventionally managed fields (Gabriel et al. 2006; Salonen et al. 2011; Rydberg and Milberg 2012; Albrecht et al. 2016). This also emphasizes the conservation opportunity in urban ecosystems for rare species outside their natural conservation area (Planchuelo et al. 2019).

Furthermore, gardens may expand the natural habitats of endangered species through intentional planting or accidental introduction. For example, we found Galium spurium in a raised bed in a rooftop community garden. This typical field plant was extinct in Berlin (Seitz et al. 2018), and the species could be introduced with substrate or planting material. Thus, even novel ecosystems like rooftop gardens can contribute to urban biodiversity (Orsini et al. 2014; Walters and Midden 2018) and be a surprising reservoir for endangered plant species.

Among the cultivated species there were 13 more species with conservation relevance, including arable weeds like Agrostemma githago and Centaurea cyanus. However, in most cases these species are presumably cultivars or their origin was unknown. Even though the Red List status usually refers to wild populations or regional provenances, these examples show the potential of gardens as habitats for rare and threatened species. In these cases, the use of regional provenances can lead to the conservation or reintroduction of rare species with benefits for biodiversity conservation (Fischer et al. 2013; Lang et al. 2016, 2021; Albrecht et al. 2016).

\section{Gardens are diverse regardless of landscape-scale imperviousness, though local scale imperviousness may reduce potential for high diversity}

The plant diversity harbored and cultivated within these community gardens can be high regardless of where these gardens are located in the urban landscape, emphasizing that landscape-scale imperviousness does not necessarily determine local alpha diversity. This also underscores the potential for gardens to be valuable for plant diversity, plant 
species conservation, and urban food production, regardless of their position in the city landscape. However, at the local scale, imperviousness within gardens negatively predicts local plant species richness. Perhaps this negative correlation is of no surprise: higher sealing reduces habitats for plants at the local level (Scalenghe and Ajmone-Marsan 2009; Yan et al. 2019). In gardens with low imperviousness habitat diversity is higher because there are not only beds for growing crops, but also grassland, margins and ruderal areas of predominantly extensive management (Fig. 2c, d). Yet, instead we propose that highly sealed gardens are a space for management intervention. Imperviousness at the local scale could be reduced - especially with unsealing measures, or by increasing the number of raised beds or other forms of vegetated interventions - to dampen the negative relationship and heighten habitats especially for wild growing plants. Reduced sealing also has a positive effect on water conservation, soil moisture, heating effects (Scalenghe and Ajmone-Marsan 2009; Lin et al. 2018a), and on other trophic levels of biodiversity (Geslin et al. 2016; Rocha and Fellowes 2018; Levé et al. 2019; Egerer et al. 2019a).

Our findings also have policy implications: gardens that include habitats analogues to (semi)natural systems in cities can support biodiversity conservation. In Berlin, this includes community gardens with or within fields and grasslands, which had some of the highest plant richness values across all gardens and contained many of the Red List species. These systems cannot be replaced with novel container gardens that arise on rooftops or within unused parking lots. These sealed surfaces require more effort to increase and maintain plant species richness, especially for wild plants. While such novel garden systems are often very socially valuable (Gregory et al. 2016), cities need to implement policies that prevent development and protect gardens that exist outside of sealed areas to best conserve the remaining species diversity that it has.

\section{Cultivated and wild plants can coexist - and potentially synergize - in urban gardens}

We found evidence for synergies among cultivated and wild plants in gardens, with species abundance and richness of cultivated plants (food crops, ornamentals) positively correlated with wild plant species richness in gardens. This challenges traditional narratives that position food production at odds with biodiversity conservation (Phalan et al. 2011; Gabriel et al. 2013). Rather than posing wild plant species abundance and richness at odds with production, our results reconcile production-conservation goals and illuminate potential synergies among food production, biodiversity, and potential ecological functions within urban community gardens. These are unique systems where we can reconsider and reformulate contemporary paradigms of "land sharing' versus 'land sparing' (Lin and Fuller 2013; Collas et al. 2017). Our study provides an important contribution to the literature by showing that in urban community gardens, the principle of land sharing is implemented through the simultaneous cultivation of crops and the conservation of wild plants. The social context of these gardens may here be decisive. Though we did not investigate motivations to garden or the socio-cultural context of gardeners, if urban food production is less essential here than in other regions of the world, wild species may not be immediately managed as weeds, and rather allowed space to grow alongside cultivated neighbors. Surveys about the motivation of gardeners in urban gardens generally showed that there is also interest in contact with nature (Armstrong 2000; Breuste and Artmann 2014; Pourias et al. 2016), which could be an opportunity for the acceptance and integration for wild growing plants.

\section{Limitations and future directions}

Our work is limited in that our random sampling may not be totally comprehensive of all plant species within the gardens. However, the standard assessment means that we are able to provide comparative assessments between gardens, and an assessment within a given standardized area. Future investigations that have more time and resources can expand this to study plants within the entire gardens, and also how plant diversity may be related to other factors such as garden size, which could relate to the species pool of a garden and thereby be an important factor driving spontaneous and anthropogenic seed dispersal. In addition, we did not determine the cultivars for crops. This motivates future studies to explore the diversity of different cultivars within common crops like Beta vulgaris, Cucurbita pepo, Solanum lycopersicum, and Lactuca sativa. Such work on cultivars could also contribute to informing how the diversity of crops relates to the conservation of e.g., wild pollinators and pollination function or biological pest control in these gardens, specifically in relation to urban food production.

\section{Conclusion}

A popular debate in the scientific and planning community is whether or not land sharing or land sparing is the best solution to conserve biodiversity and maintain ecosystem functions that support society (Fischer et al. 2014; Grass et al. 2019). Do we intensify agricultural production within agricultural landscapes to set aside other land for biodiversity? Do we densify our cities, removing remnant forests and grassland, to spare land outside city boundaries for nature conservation? Such conflicts plague discourse and decisions in urban areas on how to provision green spaces and densify urban neighborhoods (Lin and Fuller 2013; Stott et al. 
2015). As many cities lose green spaces for plant diversity and conservation, an open question is how to balance their 'natural' history with the contemporary pressure to seal the soils that are its seedbank.

Urban community gardens have risen as a popular social and ecological movement to reclaim some vegetated habitats within the densifying environment. Community gardens are a nexus of urban food production, urban greening, humannature connection and public health - and can also be refugia for diverse wild growing plant communities (Cabral et al. 2017; Lin et al. 2018b; Lin and Egerer 2020). Our work here contributes to our understanding of the growing importance of plant diversity conservation within these urban ecosystems. The plant diversity of gardens has wide implications for animal biodiversity, species interactions, and ecosystem functions, for example, the protection of wild pollinators and pollination services (Makinson et al. 2016; Baldock et al. 2019; Tasker et al. 2019; Egerer et al. 2019a). This potential for conservation is particularly interesting as community gardens are primarily established for food production (Corrigan 2011; Gregory et al. 2016) and recreational reasons (Breuste and Artmann 2014), and suggests that the possibility for species conservation can be further heightened by raising awareness for biodiversity management through the conservation of wild growing plants. In Berlin, there are already initiatives and projects to involve citizen scientists into the propagation and cultivation of threatened plant species in gardens (Fišer et al. 2021), which should be accompanied by conservation authorities and Botanical Gardens (Godefroid et al. 2011; Lauterbach et al. 2019). Thus, community gardens can present a system for reconciliation ecology: anthropogenic habitats that are modified to harbor a wide variety of species (Rosenzweig 2003). Gardens are where we may best conserve species where people live, work and play. In sum, regardless of their built context, gardens across a city can support a wide range of plant species, where both human needs and nature's biological diversity can coexist.

Supplementary Information The online version contains supplementary material available at https://doi.org/10.1007/s11252-021-01198-0.

Acknowledgements We thank the land owners and the community gardeners for supporting this work in their gardens: AllmendeKontor, Gemeinschaftsgarten am Burbacher Weg, Himmelbeet, Inselgarten Schöneberg, Kiezgarten Fischerstrasse, KlunkerGarten in der Horstwirtschaft e.V., Nachbarschaftsgarten Wiecker Straße, Garten der Begegnung, Peace of Land, Pflanz Was VattenfallGemeinschaftsgarten Neue Grünstraße, prinzessinnengarten kollektiv berlin, Rote Beete, Schalottengarten, Spiel/Feld Marzahn, Vollguter Gemeinschaftsgarten, Gemeinschaftsgarten Wachsenlassen, Gartenarbeitsschule Tempelhof-Schöneberg, Gartenarbeitsschule Friedrichshain-Kreuzberg. Thank you to Anne Hiller for collecting the spatial data. Thank you to Ulrike Sturm and the Museum of Natural History in Berlin for project support. Thank you to Moritz von der Lippe, Martin Penzel, Carolina Achilles, Julia Felderhoff, and Anika Gathof for supporting field work. Thank you to Editor Michael Strohbach and two anonymous reviewers for providing valuable feedback on the manuscript.

Authors' contributions B.S, M.E. and S.B. conceived of the study. B.S., J.H., L.N., J.W., L.W., and M.E. carried out the data collection (field surveys). B.S. and M.E. analyzed the data. B.S. and M.E. drafted the manuscript with contributions from all authors.

Funding Open Access funding enabled and organized by Projekt DEAL. This work was funded by an International Postdoctoral Fellowship from the Technical University of Berlin (M.E.) and the German Federal Ministry of Education and Research (BMBF) within the Collaborative Project "Bridging in Biodiversity Science- BIBS", (funding number 01LC1501A-H) (S.B., I.K.).

Availability of data and material All data available in the supporting information or available upon request.

Code availability Code available upon request.

\section{Declarations}

Ethics approval All sites were sampled and surveyed with written or verbal permission from land managers.

Additional declarations for articles in life science journals that report the results of studies involving humans and/or animals Not applicable.

Consent to participate All gardens confirmed participation in the research.

Consent for publication All authors confirm submission to the Journal.

Conflicts of interest/Competing interests Not applicable.

Open Access This article is licensed under a Creative Commons Attribution 4.0 International License, which permits use, sharing, adaptation, distribution and reproduction in any medium or format, as long as you give appropriate credit to the original author(s) and the source, provide a link to the Creative Commons licence, and indicate if changes were made. The images or other third party material in this article are included in the article's Creative Commons licence, unless indicated otherwise in a credit line to the material. If material is not included in the article's Creative Commons licence and your intended use is not permitted by statutory regulation or exceeds the permitted use, you will need to obtain permission directly from the copyright holder. To view a copy of this licence, visit http://creativecommons.org/licenses/by/4.0/.

\section{References}

Alaimo K, Packnett E, Miles RA, Kruger DJ (2008) Fruit and vegetable intake among urban community gardeners. J Nutr Educ Behav Educ Behav 40:94-101. https://doi.org/10.1016/j.jneb.2006.12.003

Albrecht H, Cambecèdes J, Lang M, Wagner M (2016) Management options for the conservation of rare arable plants in Europe. Bot Lett 163(4):389-415. https://doi.org/10.1080/23818107.2016. 1237886

Armstrong D (2000) A survey of community gardens in upstate New York: implications for health promotion and community development. Health Place 6:319-327 
Aronson MFJ, Nilon CH, Lepczyk CA et al (2016) Hierarchical filters determine community assembly of urban species pools. Ecology 97:2952-2963

Baldock KCR, Goddard MA, Hicks DM et al (2019) A systems approach reveals urban pollinator hotspots and conservation opportunities. Nat Ecol Evol 3:363-373. https://doi.org/10.1038/ s41559-018-0769-y

Bang C, Faeth SH, Sabo JL (2012) Control of arthropod abundance, richness, and composition in a heterogeneous desert city. Ecol Monogr 82:85-100. https://doi.org/10.1890/11-0828.1

Barthel S, Isendahl C (2013) Urban gardens, agriculture, and water management: sources of resilience for long-term food security in cities. Ecol Econ 86:224-234. https://doi.org/10.1016/j.ecolecon. 2012.06.018

Bonthoux S, Brun M, Di Pietro F et al (2014) How can wastelands promote biodiversity in cities? A review. Landsc Urban Plan 132:7988. https://doi.org/10.1016/J.LANDURBPLAN.2014.08.010

Borysiak J, Mizgajski A, Speak A (2017) Floral biodiversity of allotment gardens and its contribution to urban green infrastructure. Urban Ecosyst 20:323-335. https://doi.org/10.1007/ s11252-016-0595-4

Breuste JH, Artmann M (2014) Allotment gardens contribute to urban ecosystem service: case study Salzburg. Austria J Urban Plan Dev 141:A5014005. https://doi.org/10.1061/(ASCE)UP.19435444.0000264

Buchholz S, Gathof AK, Grossmann AJ et al (2020) Wild bees in urban grasslands: Urbanisation, functional diversity and species traits. Landsc Urban Plan 196:103731. https://doi.org/10.1016/j. landurbplan.2019.103731

Burnham KP, Anderson DR (2002) Model selection and multimodel inference: A practical information-Theoretic Approach. Springer, New York

Cabral I, Keim J, Engelmann R et al (2017) Ecosystem services of allotment and community gardens: A Leipzig, Germany case study. Urban for Urban Green 23:44-53. https://doi.org/10. 1016/j.ufug.2017.02.008

Cameron RWF, Blanuša T, Taylor JE et al (2012) The domestic garden - Its contribution to urban green infrastructure. Urban for Urban Green 11:129-137. https://doi.org/10.1016/J.UFUG.2012.01.002

Čepić S, Tomićević-Dubljević J (2017) Urban community and allotment gardens: Research trends and a look ahead. Agric For. https://doi.org/10.17707/AgricultForest.63.4.20

Clarke LW, Jenerette GD (2015) Biodiversity and direct ecosystem service regulation in the community gardens of Los Angeles, CA. Landsc Ecol. https://doi.org/10.1007/s10980-014-0143-7

Clucas B, Parker ID, Feldpausch-Parker AM (2018) A systematic review of the relationship between urban agriculture and biodiversity. Urban Ecosyst 21:635-643. https://doi.org/10.1007/ s11252-018-0748-8

Collas L, Green RE, Ross A et al (2017) Urban development, land sharing and land sparing: the importance of considering restoration. $\mathrm{J}$ Appl Ecol 54:1865-1873. https://doi.org/10.1111/1365-2664.12908

Corrigan MP (2011) Growing what you eat: Developing community gardens in Baltimore, Maryland. Appl Geogr 31:1232-1241. https://doi.org/10.1016/j.apgeog.2011.01.017

Daniels GD, Kirkpatrick JB (2006) Does variation in garden characteristics influence the conservation of birds in suburbia? Biol Conserv 133:326-335. https://doi.org/10.1016/J.BIOCON.2006. 06.011

Davies Z, Fuller RA, Irvine KN, Gaston KJ (2009) A national scale inventory of resource provision within domestic gardens. Biol Conserv 142:761-771. https://doi.org/10.1016/j.biocon.2008. 12.016

Egerer M, Cecala J, Cohen H (2019a) Wild Bee Conservation within Urban Gardens and Nurseries: Effects of Local and Landscape
Management. Sustainability 12:293. https://doi.org/10.3390/ su12010293

Egerer MH, Lin BB, Threlfall CG, Kendal D (2019b) Temperature variability influences urban garden plant richness and gardener water use behavior, but not planting decisions. Sci Total Environ 646:111-120. https://doi.org/10.1016/j.scitotenv.2018.07.270

Faeth SH, Bang C, Saari S (2011) Urban biodiversity: patterns and mechanisms. Ann N Y Acad Sci 1223:69-81. https://doi.org/10. 1111/j.1749-6632.2010.05925.x

Faeth SH, Marussich WA, Shochat E, Warren PS (2005) Trophic dynamics in urban communities. Bioscience 55:399. https://doi. org/10.1641/0006-3568(2005)055[0399:TDIUC]2.0.CO;2

Fischer J, Abson DJ, Butsic V et al (2014) Land sparing versus land sharing: Moving forward. Conserv Lett 7:149-157. https://doi. org/10.1111/conl.12084

Fischer LK, Rodorff V, von der Lippe M (2016) Kowarik I (2016) Drivers of biodiversity patterns in parks of a growing South American megacity. Urban Ecosyst 193(19):1231-1249. https://doi.org/10. 1007/S11252-016-0537-1

Fischer LK, von der Lippe M, Kowarik I (2013) Urban land use types contribute to grassland conservation: The example of Berlin. Urban for Urban Green 12:263-272. https://doi.org/10.1016/J. UFUG.2013.03.009

Fišer Ž, Aronne G, Aavik T et al (2021) ConservePlants: An integrated approach to conservation of threatened plants for the 21 st Century. Res Ideas Outcomes. https://doi.org/10.3897/ rio.7.e62810

Frey D, Moretti M (2019) A comprehensive dataset on cultivated and spontaneously growing vascular plants in urban gardens. Data $\mathrm{Br}$ 25:103982. https://doi.org/10.1016/j.dib.2019.103982

Gabriel D, Roschewitz I, Tscharntke T, Thies C (2006) Beta diversity at different spatial scales: Plant communities in organic and conventional agriculture. Ecol Appl 16(5):2011-2021. https:// doi.org/10.1890/1051-0761(2006)016[2011:BDADSS]2.0.CO;2

Gabriel D, Sait SM, Kunin WE, Benton TG (2013) Food production vs. biodiversity: comparing organic and conventional agriculture. J Appl Ecol 50:355-364. https://doi.org/10.1111/1365-2664.12035

Galluzzi G, Eyzaguirre P, Negri V (2010) Home gardens: neglected hotspots of agro-biodiversity and cultural diversity. Biodivers Conserv 19:3635-3654. https://doi.org/10.1007/s10531-010-9919-5

Gaston KJ, Smith RM, Thompson K, Warren PH (2005) Urban domestic gardens (II): experimental tests of methods for increasing biodiversity. Biodivers Conserv 14:395-413. https://doi.org/10. 1007/s 10531-004-6066-x

Geslin B, Le Féon V, Folschweiller M et al (2016) The proportion of impervious surfaces at the landscape scale structures wild bee assemblages in a densely populated region. Ecol Evol 6:65996615. https://doi.org/10.1002/ece3.2374

Goddard MA, Dougill AJ, Benton TG (2010) Scaling up from gardens: biodiversity conservation in urban environments. Trends Ecol Evol 25:90-98. https://doi.org/10.1016/j.tree.2009.07.016

Godefroid S, Piazza C, Rossi G et al (2011) How successful are plant species reintroductions? Biol Conserv 144:672-682. https://doi. org/10.1016/J.BIOCON.2010.10.003

Grass I, Loos J, Baensch S et al (2019) Land-sharing/-sparing connectivity landscapes for ecosystem services and biodiversity conservation. People Nat pan3.21. https://doi.org/10.1002/pan3.21

Gregory MM, Leslie TW, Drinkwater LE (2016) Agroecological and social characteristics of New York city community gardens: contributions to urban food security, ecosystem services, and environmental education. Urban Ecosyst 19:763-794. https://doi. org/10.1007/s11252-015-0505-1

Guitart D, Pickering C, Byrne J (2012) Past results and future directions in urban community gardens research. Urban for Urban Green 11:364-373. https://doi.org/10.1016/j.ufug.2012.06.007 
Jaganmohan M, Vailshery LS, Gopal D, Nagendra H (2012) Plant diversity and distribution in urban domestic gardens and apartments in Bangalore. India Urban Ecosyst 15(4):911-925. https:// doi.org/10.1007/S11252-012-0244-5

Jäger EJ, Ebel F, Hanelt P, Müller GK (2016) Rothmaler-Exkursionsflora von Deutschland: Krautige Zier-und Nutzpflanzen. Springer-Verlag

Jäger EJ, Müller F, Ritz C et al (2017) Rothmaler-Exkursionsflora von Deutschland. Grundband Springer-Verlag, Gefäßpflanzen

Kabisch N, Haase D (2014) Green justice or just green? Provision of urban green spaces in Berlin, Germany. Landsc Urban Plan 122:129-139. https://doi.org/10.1016/j.landurbplan.2013.11.016

Kaluza BF, Wallace HM, Heard TA et al (2018) Social bees are fitter in more biodiverse environments. Sci Rep 8:1-10. https://doi.org/ 10.1038/s41598-018-30126-0

Kendal D, Williams NSG, Williams KJH (2012) A cultivated environment: Exploring the global distribution of plants in gardens, parks and streetscapes. Urban Ecosyst 15:637-652. https://doi. org/10.1007/s11252-011-0215-2

Knapp S, Kühn I, Bakker JP et al (2009) How species traits and affinity to urban land use control large-scale species frequency. Divers Distrib 15:533-546. https://doi.org/10.1111/j.1472-4642.2009. 00561.x

Kowarik I (2011) Novel urban ecosystems, biodiversity, and conservation. Environ Pollut 159:1974-1983. https://doi.org/10.1016/j. envpol.2011.02.022

Kowarik I (2005) Wild urban woodlands: Towards a conceptual Framework. In Wild Urban Woodlands. Springer-Verlag, Berlin/Heidelberg, pp 1-32

Kowarik I (2019) The "Green Belt Berlin": Establishing a greenway where the Berlin Wall once stood by integrating ecological, social and cultural approaches. Landsc Urban Plan 184:12-22. https://doi.org/10.1016/j.landurbplan.2018.12.008

Kowarik I, Buchholz S, von der Lippe M, Seitz B (2016) Biodiversity functions of urban cemeteries: Evidence from one of the largest Jewish cemeteries in Europe. Urban for Urban Green 19:68-78. https://doi.org/10.1016/J.UFUG.2016.06.023

Kowarik I, Hiller A, Planchuelo G, Seitz B (2019) Emerging urban forests: Opportunities for promoting the wild side of the urban green infrastructure. Sustainability 11:1-27. https://doi.org/10. 3390/su11226318

Krausch HD (1992) Alte Nutz- und Zierpflanzen in der Niederlausitz. Verh Bot Ver Berlin Brand 2:1-100

Krausch HD (2007) Kaiserkron und Paeonien rot. Entdeckung und Einführung unserer Gartenblumen. Dölling \& Galitz

Kronenberg B, Kowarik I (1989) Naturverjüngung kultivierter Pflanzen in Gärten. Verhandlungen Des Berliner Bot Vereins 7:3-30

Kühn I, Brandl R, Klotz S (2004) The flora of German cities is naturally species rich. Evol Ecol Res 6:749-764

Lang M, Kollmann J, Prestele J et al (2021) Reintroduction of rare arable plants in extensively managed fields: Effects of crop type, sowing density and soil tillage. Agric Ecosyst Environ 306:107187. https://doi.org/10.1016/J.AGEE.2020.107187

Lang M, Prestele J, Fischer C et al (2016) Reintroduction of rare arable plants by seed transfer. What are the optimal sowing rates? Ecol Evol 6:5506-5516. https://doi.org/10.1002/ECE3.2303

Lauterbach D, Burkart M, Dreilich A (2019) Beiträge der Botanischen Gärten Potsdam und Berlin zum Botanischen Artenschutz in Brandenburg. Naturschutz Und Landschaftspfl Brand 28:4-23

Levé M, Baudry E, Bessa-Gomes C (2019) Domestic gardens as favorable pollinator habitats in impervious landscapes. Sci Total Environ 647:420-430. https://doi.org/10.1016/j.scitotenv.2018.07.310

Lin BB, Egerer MH (2020) Global social and environmental change drives the management and delivery of ecosystem services from urban gardens: A case study from Central Coast, California. Glob Environ Chang 60:1-10. https://doi.org/10.1016/j.gloenvcha. 2019.102006
Lin BB, Egerer MH, Liere H et al (2018a) Local- and landscape-scale land cover affects microclimate and water use in urban gardens. Sci Total Environ 610-611:570-575. https://doi.org/10.1016/j. scitotenv.2017.08.091

Lin BB, Egerer MH, Ossola A (2018b) Urban gardens as a space to engender biophilia: Evidence and ways forward. Front Built Environ 4:1-10. https://doi.org/10.3389/fbuil.2018.00079

Lin BB, Fuller RA (2013) Sharing or sparing? How should we grow the world's cities? J Appl Ecol 50:1161-1168. https://doi.org/10. 1111/1365-2664.12118

Lin BB, Philpott SM, Jha S (2015) The future of urban agriculture and biodiversity-ecosystem services: challenges and next steps. Basic Appl Ecol 16:189-201. https://doi.org/10.1016/j.baae. 2015.01.005

Löki V, Deák B, Lukács AB, Molnár VA (2019) Biodiversity potential of burial places - a review on the flora and fauna of cemeteries and churchyards. Glob Ecol Conserv 18:e00614. https://doi.org/ 10.1016/J.GECCO.2019.E00614

Loram A, Thompson K, Warren PH, Gaston KJ (2008) Urban domestic gardens (XII): The richness and composition of the flora in five UK cities. J Veg Sci 19:321-330. https://doi.org/10.3170/2007-8-18373

Lososová Z, Chytrý M, Tichý L et al (2012) Biotic homogenization of Central European urban floras depends on residence time of alien species and habitat types. Biol Conserv 145:179-184. https://doi. org/10.1016/J.BIOCON.2011.11.003

Makinson JC, Threlfall CG Latty T (2016) Bee-friendly community gardens: Impact of environmental variables on the richness and abundance of exotic and native bees. Urban Ecosyst 202(20):463-476. https://doi.org/10.1007/S11252-016-0607-4

Metzing D, Garve E, Matzke-Hajek G, Adler J, Bleeker W, Breunig T, Caspari S, Dunkel FG, Fritsch R, Gottschlich G, Gregor T (2018) Rote Liste und Gesamtartenliste der Farn-und Blütenpflanzen (Trachaeophyta) Deutschlands. Naturschutz Und Biologische Vielfalt 70(7):13-358

Orsini F, Gasperi D, Marchetti L et al (2014) Exploring the production capacity of rooftop gardens (RTGs) in urban agriculture: the potential impact on food and nutrition security, biodiversity and other ecosystem services in the city of Bologna. Food Secur 66(6):781-792. https://doi.org/10.1007/S12571-014-0389-6

Padullés Cubino J, Cavender-Bares J, Groffman PM et al (2020) Taxonomic, phylogenetic, and functional composition and homogenization of residential yard vegetation with contrasting management. Landsc Urban Plan 202:103877. https://doi.org/10.1016/J. LANDURBPLAN.2020.103877

Padullés Cubino J, Cavender-Bares J, Hobbie SE et al (2018) Drivers of plant species richness and phylogenetic composition in urban yards at the continental scale. Landsc Ecol. https://doi.org/10. 1007/s10980-018-0744-7

Pergl J, Sádlo J, Petrík P, Danihelka J, Chrtek HM Jr, Hejda M, Moravcová L, Perglová I, Štajerová K, Pyšek P (2016) Dark side of the fence: ornamental plants as a source of wildgrowing flora in the Czech Republic. Preslia 88:163-184

Phalan B, Onial M, Balmford A, Green RE (2011) Reconciling Food Production and Biodiversity Conservation: Land Sharing and Land Sparing Compared. Science (80- ) 333:1289-1291. https://doi.org/ 10.1126/science. 1208742

Philpott S, Bichier P (2017) Local and landscape drivers of predation services in urban gardens. Ecol Appl. https://doi.org/10.1111/ ijlh. 12426

Philpott SM, Egerer MH, Bichier P et al (2020) Gardener demographics, experience, and motivations drive differences in plant species richness and composition in urban gardens. Ecol Soc 25:art8. https://doi.org/10.5751/ES-11666-250408

Piana MR, Aronson MFJ, Pickett STA, Handel SN (2019) Plants in the city: understanding recruitment dynamics in urban landscapes. Front Ecol Environ 17:455-463. https://doi.org/10.1002/fee.2098 
Planchuelo G, Kowarik I, von der Lippe M (2020) Plant traits, biotopes and urbanization dynamics explain the survival of endangered urban plant populations. J Appl Ecol 57:1581-1592. https://doi. org/10.1111/1365-2664.13661

Planchuelo G, Von Der LM, Kowarik I (2019) Untangling the role of urban ecosystems as habitats for endangered plant species. Landsc Urban Plan 189:320-334. https://doi.org/10.1016/j.landurbplan. 2019.05.007

Pourias J, Aubry C, Duchemin E (2016) Is food a motivation for urban gardeners? Multifunctionality and the relative importance of the food function in urban collective gardens of Paris and Montreal. Agric Human Values 33:257-273. https://doi. org/10.1007/s10460-015-9606-y

Pyšek P, Bacher S, Chytrý M et al (2010) Contrasting patterns in the invasions of European terrestrial and freshwater habitats by alien plants, insects and vertebrates. Glob Ecol Biogeogr 19:317-331. https://doi.org/10.1111/J.1466-8238.2009.00514.X

QGIS Development Team (2018) QGIS Geographic Information System: Open Source Geospatial Foundation. http://qgis.osgeo.org. Accessed 27 Dec 2019

R Development Core Team (2016) R Development Core Team. R A Lang Environ Stat Comput 55:275-286

Rocha EA, Fellowes MDE (2018) Does urbanization explain differences in interactions between an insect herbivore and its natural enemies and mutualists? Urban Ecosyst 21:405-417. https://doi.org/10.1007/s11252-017-0727-5

Rosenzweig ML (2003) Reconciliation ecology and the future of species diversity. Oryx 37:194-205. https://doi.org/10.1017/ S0030605303000371

Rydberg NT, Milberg P (2012) A Survey of Weeds in Organic Farming in Sweden. Biol Agri Hortic 18:175-185. https://doi.org/ 10.1080/01448765.2000.9754878

Salonen J, Hyvönen T, Jalli H (2011) Composition of weed flora in spring cereals in Finland - a fourth survey. Agric Food Sci 20:245-261. https://doi.org/10.2137/145960611797471534

Scalenghe R, Ajmone-Marsan F (2009) The anthropogenic sealing of soils in urban areas. Landsc Urban Plan 90:1-10. https://doi.org/ 10.1016/J.LANDURBPLAN.2008.10.011

Schneider C, Sukopp U, Sukopp H (1994) Biologisch-ökologische Grundlagen des Schutzes gefährdeter Segetalpflanzen. Schriftenr Veg 26:1-356

Seitz B, Ristow M et al (2018) Rote Liste und Gesamtartenliste der etablierten Farn- und Blütenpflanzen von Berlin. In: der landesbeauftragte für naturschutz und landschaftspflege / senatsverwaltung für umwelt, klima und verkehr (Ed.): Rote Listen der gefährdeten Pflanzen, Pilze und Tiere von Berlin. https://doi.org/ 10.14279/depositonce-6689

Seitz B, Ristow M, Prasse R et al (2012) Der Berliner Florenatlas. Verh Bot Ver Berlin Brand 7:1-533

Senatsverwaltung für Stadtentwicklung und Umwelt (2016) Versorgung mit öffentlichen, wohnungsnahen Grünanlagen. In: Umweltatlas. https://www.stadtentwicklung.berlin.de/umwelt/umweltatlas/ index.shtml. Accessed 12 Nov 2019

Shrewsbury PM, Lashomb JH, Hamilton GC et al (2004) The influence of flowering plants on herbivore and natural enemy abundance in ornamental landscapes. Int J Ecol Environ Sci 30:23-33

Smith RM, Thompson K, Hodgson JG et al (2006) Urban domestic gardens (IX): Composition and richness of the vascular plant flora, and implications for native biodiversity. Biol Conserv 129:312-322. https://doi.org/10.1016/j.biocon.2005.10.045

Stott I, Soga M, Inger R, Gaston KJ (2015) Land sparing is crucial for urban ecosystem services. Front Ecol Environ 13:387-393. https://doi.org/10.1890/140286
Swan CM, Brown B, Borowy D et al (2021) A framework for understanding how biodiversity patterns unfold across multiple spatial scales in urban ecosystems. Ecosphere. https://doi.org/10.1002/ ecs 2.3650

Tasker P, Reid C, Young AD et al (2019) If you plant it, they will come: quantifying attractiveness of exotic plants for winter-active flower visitors in community gardens. Urban Ecosyst 23(2):345354. https://doi.org/10.1007/S11252-019-00914-1

Taylor J, Mione T (2019) Collection of Jaltomata darcyana (Solanaceae), previously unrecorded in cultivation, from a home garden in Chicago, IL Renew Agric Food Syst 1-3. https://doi.org/10. 1017/S1742170519000127

Thompson K, Austin KC, Smith RM et al (2003) Urban domestic gardens (I): Putting small-scale plant diversity in context. J Veg Sci 14:71. https://doi.org/10.1658/1100-9233(2003)014[0071: UDGIPS]2.0.CO;2

Threlfall CG, Mata L, Mackie JA et al (2017) Increasing biodiversity in urban green spaces through simple vegetation interventions. J Appl Ecol. https://doi.org/10.1111/1365-2664.12876

Trentanovi G, von der Lippe M, Sitzia T et al (2013) Biotic homogenization at the community scale: disentangling the roles of urbanization and plant invasion. Divers Distrib 19:738-748. https://doi. org/10.1111/DDI.12028

UN-Habitat (2016) World Cities Report 2016: Urbanization and Development: Emerging Futures. United Nations Human Settlements Programme (UN-Habitat). https://unhabitat.org/ world-cities-report

Van Helden BE, Close PG, Steven R (2020) Mammal conservation in a changing world: can urban gardens play a role? Urban Ecosyst 23:555-567. https://doi.org/10.1007/s11252-020-00935-1

van Kleunen M, Essl F, Pergl J et al (2018) The changing role of ornamental horticulture in alien plant invasions. Biol Rev 93:14211437. https://doi.org/10.1111/BRV.12402

Vergnes A, Kerbiriou C, Clergeau P (2013) Ecological corridors also operate in an urban matrix: A test case with garden shrews. Urban Ecosyst. https://doi.org/10.1007/s11252-013-0289-0

Vojík M, Sádlo J, Petřík P et al (2020) Two faces of parks. Preslia 92:353-373. https://doi.org/10.23855/preslia.2020.353

von der Lippe M, Buchholz S, Hiller A et al (2020) CityScapeLab Berlin: A Research Platform for Untangling Urbanization Effects on Biodiversity. Sustainability 12:2565. https://doi.org/10.3390/ su12062565

von der Lippe M, Kowarik I (2009) Do cities export biodiversity? Traffic as dispersal vector across urban-rural gradients. Divers Distrib 14:18-25. https://doi.org/10.1111/j.1472-4642,2007.00401.x

Walters SA, Midden KS (2018) Sustainability of Urban Agriculture: Vegetable Production on Green Roofs. Agric 8:168. https://doi. org/10.3390/AGRICULTURE8110168

Westermann JR, von der Lippe M, Kowarik I (2011) Seed traits, landscape and environmental parameters as predictors of species occurrence in fragmented urban railway habitats. Basic Appl Ecol 12:29-37. https://doi.org/10.1016/J.BAAE.2010.11.006

Yan Z, Teng M, He W et al (2019) Impervious surface area is a key predictor for urban plant diversity in a city undergone rapid urbanization. Sci Total Environ 650:335-342. https://doi.org/10.1016/j. scitotenv.2018.09.025

Zerbe S, Maurer U, Schmitz S, Sukopp H (2003) Biodiversity in Berlin and its potential for nature conservation. Landsc Urban Plan 62:139-148. https://doi.org/10.1016/S0169-2046(02)00145-7 